\title{
Optimization of the machining parameters for EDM wire cutting of Tungsten Carbide
}

\author{
Gaurav Kumar ${ }^{1, a}$, J S Tiwana ${ }^{2}$ and Ashish Singla ${ }^{3}$ \\ ${ }^{1}$ Assistant Professor, Mechanical Engg. Deptt, BGIET, Sangrur, India \\ ${ }^{2}$ Assistant Professor, Mechanical Engg. Deptt, GZSCCET, Bathinda, India \\ ${ }^{3}$ Assistant Professor, Mechanical Engg. Deptt, BGIET, Sangrur, India
}

\begin{abstract}
Electrical discharge machining is a thermal erosion process which is based on thermoelectric energy between the work piece and electrode. Its capability of machining in hard and difficult to cut materials has made it most popular. Tungsten carbide is widely used in industry due to its unique properties combination of hardness and wear resistance. But the machining of the tungsten carbide is very difficult. In our research we tried to find optimized procedure to cut the Tungsten carbide by variation of different parameters so that process can be carried out in maximum Material Removal Rate (MRR) with better surface finish. During the experimentation, Brass wire is used for cutting.. The experiment is designed with the help of Taguchi method and further analysis done with the help of ANOVA. In this experiment we find that the minimum mean of surface roughness is 2.214 achieved at Tension- 0.6 N, Feed- $10 \mathrm{~m} / \mathrm{min}$, Flushing Pressure- $3 \mathrm{~kg} / \mathrm{cm}^{2}$, Current- $80 \mathrm{~A}$.
\end{abstract}

Key Words: EDM Drilling, Tungsten carbide, Surface roughness, Machining of hard materials

\section{Introduction}

Electro Discharge Machining (EDM) is a non-contact electro-thermal machining process, where electrical energy is used to generate electrical spark and material removal mainly occurs due to thermal energy of the spark. Precise machining can be done on electrically conductive and semi-conductive materials using this unconventional machining process. EDM can be used to drill circular and non-circular holes, generate profiles and make complex shaped dies of both macro and micro sizes. Both the macro EDM and the micro EDM have great potential and research work is going on in this field to improve the machining process and equipment [11]

\subsection{Principle of EDM}

EDM is a non-mechanical thermal shaping process with which material is removed by spatially and temporally separated electrical discharges between a workpiece electrode and a tool electrode. The high frequency discharges cause melting and vaporization of material on the surface of both electrodes. To enhance the material removal EDM operates in a non-conducting fluid, the dielectric fluid (Figure 1).

\footnotetext{
$\bar{a}$ Corresponding author: gaurav1588@hotmail.com
}

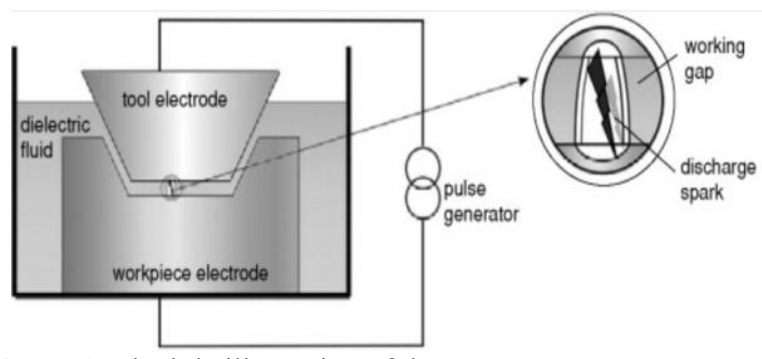

Figure 1 Principle illustration of the EDM process.

During machining, the tool and workpiece electrode are positioned in such a way that a working gap is filled with dielectric fluid remains between them.

EDM spark erosion is the same as having an electrical short that burns a small hole in a piece of metal it contacts. With the EDM process both the workpiece material and the electrode material must be conductors of electricity.

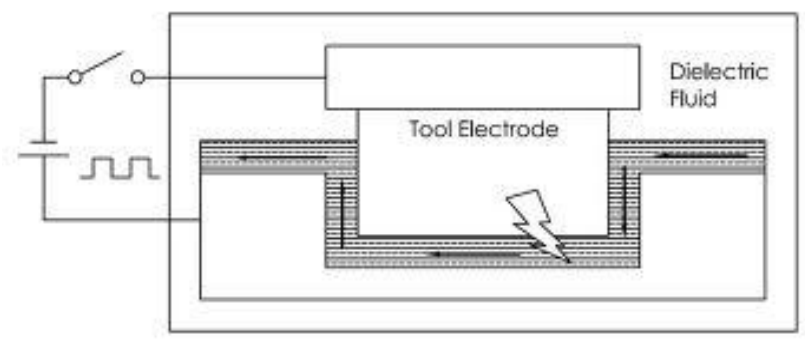

Figure 2. Sparking between the tool and work piece

The localized extreme rise in temperature leads to material removal. Material removal occurs due to instant vaporization of the material as well as due to melting. The molten metal is not removed completely, but only partially. 
The EDM process can be used in two different ways: 1. A pre-shaped or formed electrode (tool), usually made from graphite or copper, is shaped to the form of the cavity it is to reproduce. The formed electrode is fed vertically down and the reverse shape of the electrode is eroded (burned) into the solid workpiece.

2. A continuous-travelling vertical-wire electrode, the diameter of a small needle or less, is controlled by the computer to follow a programmed path to erode or cut a narrow slot through the workpiece to produce the required shape.

\section{Wire-Cut EDM}

The wire-cut EDM is a discharge machine that uses CNC movement to produce the desired contour or shape. It does not require a special shaped electrode; instead it uses a continuous-traveling vertical wire under tension as the electrode. The electrode in wire-cut EDM is about as thick as a small diameter needle whose path is controlled by the machine computer to produce the shape required.

\section{Experimental setup}

EDM machine Robofil 290, Charmilles Technologies was used as the experimental machine in this study. A Brass wire of diameter of $0.125 \mathrm{~mm}$ is used for cutting the work piece of Tungsten Carbide. The gap between work piece and electrode was flooded with a moving dielectric fluid.

Table 1 Specifications of EDM Wire Cut M/C Robofil-290 Charmillies

\begin{tabular}{|l|l|}
\hline \multicolumn{2}{|l|}{$\begin{array}{l}\text { Technical data of EDM wire cut m/c robofil-290 } \\
\text { charmillies }\end{array}$} \\
\hline Table size & $800 \times 500 \mathrm{~mm}$ \\
\hline X, y, z movement & $400 \times 250 \times 200 \mathrm{~mm}$ \\
\hline Max load capacity & $500 \mathrm{~kg}$ \\
\hline Coolant & Distilled water \\
\hline Wire to be used & Dia. $0.1-0.25 \mathrm{~mm}$ \\
\hline Accuracy & $+/-0.01 \mathrm{~mm}$ \\
\hline Water tank capacity & 300 liters \\
\hline Cutting technology & $\begin{array}{l}\text { Steel, copper, aluminium, } \\
\text { carbide, graphite }\end{array}$ \\
\hline Air pressure & $6-7$ bar \\
\hline Electricity & 400 volts, $50 \mathrm{~Hz}$ \\
\hline Speed & $0-15$ meter $/ \mathrm{min}$ \\
\hline
\end{tabular}

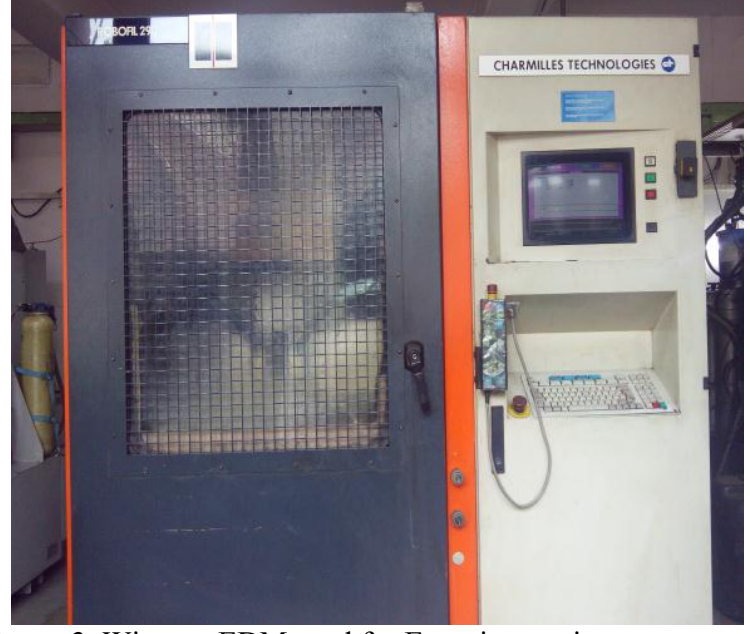

Figure 3. Wire cut EDM used for Experimentation

\section{Properties of Tungsten Carbide}

The chemical composition of Tungsten Carbide, which is tested at "Institute of Auto parts and hand tools technology, Ludhiana", is shown below in table 1.

Table 2. Chemical Composition of Tungsten Carbide

\begin{tabular}{|c|c|c|c|c|}
\hline $\begin{array}{c}\mathbf{W} \\
\%\end{array}$ & $\begin{array}{c}\text { Ni } \\
\%\end{array}$ & $\begin{array}{c}\text { Co } \\
\text { \% }\end{array}$ & $\begin{array}{c}\text { Fe } \\
\text { \% }\end{array}$ & $\begin{array}{c}\mathbf{C r} \\
\mathbf{\%}\end{array}$ \\
\hline 87.09 & 3.89 & 6.12 & 1.84 & 0.29 \\
\hline
\end{tabular}

\section{Experimental Procedure for Wire cut EDM}

Taguchi approach was taken as the basis for planning and conducting the experiments so that the appropriate data is collected which may be analyzed to obtain valid and objective conclusions

Table 3. Range of Significant Process Parameter for EDM Wire cut

\begin{tabular}{|c|c|c|c|}
\hline Parameter Name & Unit & $\begin{array}{c}\text { Lower } \\
\text { Limit }\end{array}$ & $\begin{array}{c}\text { Upper } \\
\text { Limit }\end{array}$ \\
\hline Tension & $\mathrm{N}$ & 0.6 & 1 \\
\hline Feed & $\mathrm{m} / \mathrm{min}$ & 8 & 12 \\
\hline $\begin{array}{l}\text { Flushing } \\
\text { Pressure }\end{array}$ & $\mathrm{Kg} / \mathrm{cm}^{2}$ & 2 & 4 \\
\hline Current & $\mathrm{A}$ & 60 & 100 \\
\hline
\end{tabular}

\section{Results and Analysis of Surface Roughness}


The Cutting is done on different parameter as per Design of experment. Then surface roughness is checked. In the present work Mitutoyo stylus profilometer surface roughness measurement device is used, with stylus having diamond tip. After having surface roughness following results are found.

Table 4.Observations of SR during Cutting of Tungsten Carbide

\begin{tabular}{|c|c|c|c|c|c|}
\hline $\begin{array}{c}\text { S. } \\
\text { No }\end{array}$ & SR1 & SR2 & $\begin{array}{c}\text { Mean } \\
\text { SR }\end{array}$ & S/N & MEAN \\
\hline 1 & 2.461 & 2.039 & 2.25 & -7.04365 & 2.25 \\
\hline 2 & 2.413 & 2.733 & 2.573 & -8.2088 & 2.573 \\
\hline 3 & 2.597 & 2.959 & 2.778 & -8.87465 & 2.778 \\
\hline 4 & 3.014 & 2.624 & 2.819 & -9.0019 & 2.819 \\
\hline 5 & 2.357 & 2.505 & 2.431 & -7.7157 & 2.431 \\
\hline 6 & 2.16 & 2.268 & 2.214 & -6.90356 & 2.214 \\
\hline 7 & 2.479 & 2.359 & 2.419 & -7.6727 & 2.419 \\
\hline 8 & 2.884 & 2.432 & 2.658 & -8.4911 & 2.658 \\
\hline 9 & 2.274 & 2.372 & 2.323 & -7.32098 & 2.323 \\
\hline
\end{tabular}

Table 5: Results of SR, and S/N ratios of SR

\begin{tabular}{|c|c|c|c|c|}
\hline Level & Tension & Feed & $\begin{array}{c}\text { Flushing } \\
\text { Pressure }\end{array}$ & Current \\
\hline 1 & -7.207 & -8.389 & -8.252 & -7.570 \\
\hline 2 & -8.229 & -7.478 & -7.703 & -8.260 \\
\hline 3 & -8.309 & -7.878 & -7.789 & -7.914 \\
\hline Delta & 1.102 & 0.911 & 0.549 & 0.690 \\
\hline Rank & 1 & 2 & 4 & 3 \\
\hline
\end{tabular}

Table $4 \& 5$ represents the investigated results obtained during cutting of Tungsten Carbide by utilizing EDM. The results i.e. SR and $\mathrm{S} / \mathrm{N}$ ratio were obtained.

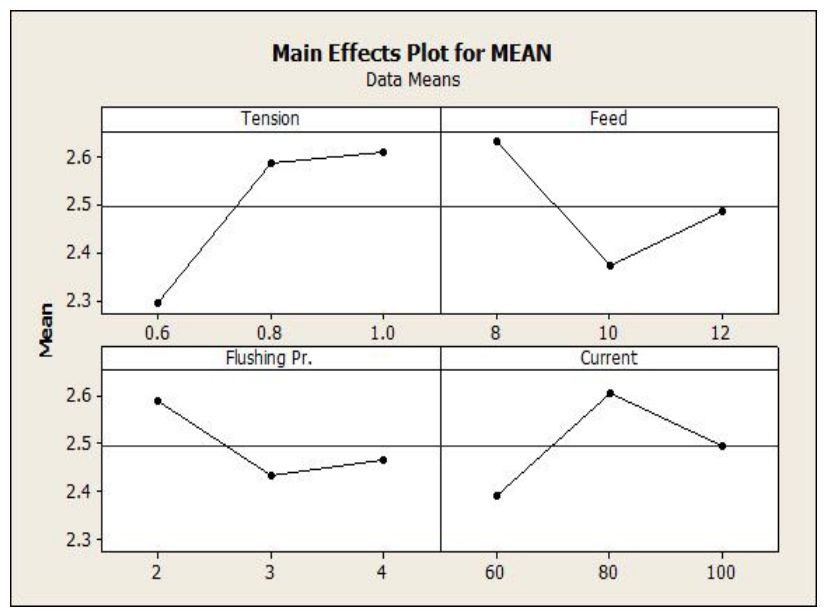

Figure 4 effect of EDM Parameters on Mean SR

Figure 4 shows effect of various EDM parameters on the surface roughness plotted utilizing the machining results obtained. From the figure, it is observed that the mean value of $\mathrm{SR}$ is increase by increasing the Tension. Increase the feed decreases the SR upto a certain limit after that SR starts increasing. SR decreases with increase in flushing pressure and remains constant after a certain value.

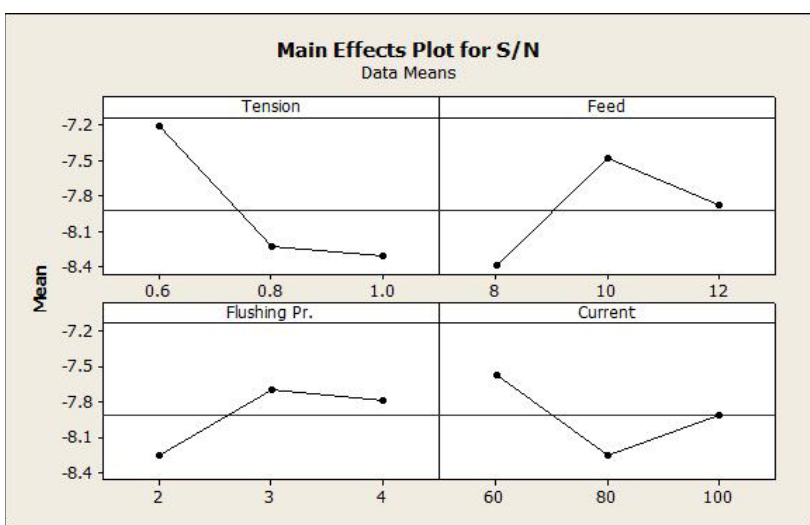

Figure 5 effect of EDM Parameters on Mean of S/N ratio of SR

Figure 5 shows effect of various EDM parameters on the mean $\mathrm{S} / \mathrm{N}$ ratio of surface roughness rate plotted utilizing the machining results obtained. From the figure, it is observed that the mean value of $\mathrm{S} / \mathrm{N}$ ratio of $\mathrm{SR}$ is decrease by increasing the Tension from 0.6 to 1 . The means of $\mathrm{S} / \mathrm{N}$ for $\mathrm{SR}$ increases with increasing the flushing pressure value from 2 to 3 and then decreases very slightly from 3 to 4 . The reverse of this happens with the current.

Taguchi Analysis: SR versus Tension, Feed, Flushing Pressure and Current

Response Table for Signal to Noise Ratio smaller is better and SR

Table 6 Ranking of EDM Parameters by Response of $\mathrm{S} / \mathrm{N}$ ratio of SR

\begin{tabular}{|l|l|l|l|l|}
\hline Level & Tension & Feed & $\begin{array}{l}\text { Flushing } \\
\text { Pressure }\end{array}$ & Current \\
\hline 1 & 2.294 & 2.632 & 2.59 & 2.391 \\
\hline 2 & 2.586 & 2.37 & 2.434 & 2.604 \\
\hline 3 & 2.608 & 2.486 & 2.464 & 2.494 \\
\hline Delta & 0.314 & 0.262 & 0.156 & 0.213 \\
\hline Rank & 1 & 2 & 4 & 3 \\
\hline
\end{tabular}

Table 7. Ranking of EDM Parameters by Response of mean of SR

\begin{tabular}{|c|c|c|c|c|c|c|c|}
\hline $\begin{array}{c}\text { S. } \\
\text { No }\end{array}$ & Tension & Feed & $\begin{array}{c}\text { Flushin } \\
\text { g } \\
\text { Pressur } \\
\mathbf{e}\end{array}$ & Current & SR1 & SR2 & $\begin{array}{c}\text { Mean } \\
\text { SR }\end{array}$ \\
\hline 1 & .6 & 12 & 4 & 100 & 2.461 & 2.039 & 2.25 \\
\hline 2 & 1 & 10 & 2 & 100 & 2.413 & 2.733 & 2.573 \\
\hline 3 & .8 & 12 & 2 & 80 & 2.597 & 2.959 & 2.778 \\
\hline 4 & 1 & 8 & 4 & 80 & 3.014 & 2.624 & 2.819 \\
\hline 5 & 1 & 12 & 3 & 60 & 2.357 & 2.505 & 2.431 \\
\hline 6 & .6 & 10 & 3 & 80 & 2.16 & 2.268 & 2.214 \\
\hline 7 & .6 & 8 & 2 & 60 & 2.479 & 2.359 & 2.419 \\
\hline 8 & .8 & 8 & 3 & 100 & 2.884 & 2.432 & 2.658 \\
\hline 9 & .8 & 10 & 4 & 60 & 2.274 & 2.372 & 2.323 \\
\hline
\end{tabular}


Above tables 6 and 7 shows the ranking of EDM parameters for optimizing the SR. It can be observed that Peak Current has the largest effect on the SR of Tungsten Carbide by machining. The pulse on has the smallest effect on the SR.

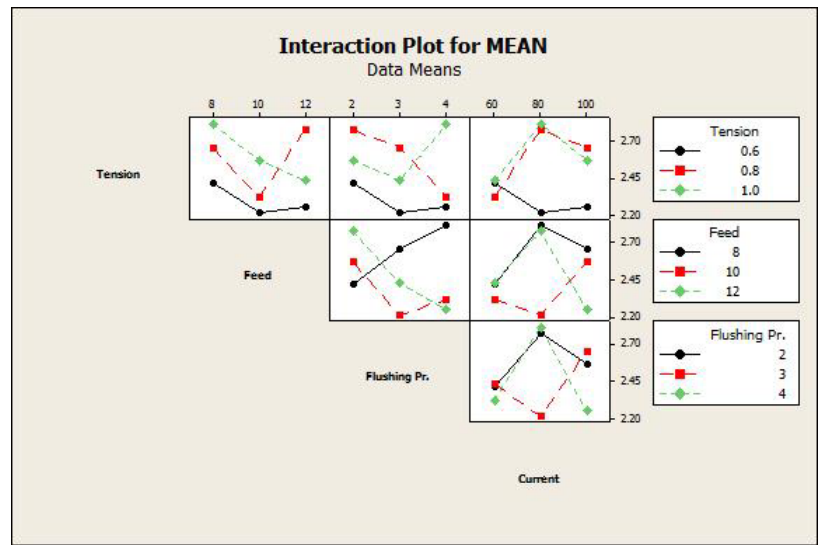

Figure 6. Interaction Plot Graph for SR

- $1^{\text {st }}$ graph is between Tension and Feed. The minimum value of $\mathrm{SR}$ is at Tension $=0.6$ and Feed $=10$.

- $2^{\text {nd }}$ graph is between Tension and Flushing Pressure. The minimum value of $\mathrm{SR}$ is at Tension=0.6 and Flushing Pressure $=3$.

- $3^{\text {rd }}$ graph is between Tension and Current. The minimum value of SR is at Tension $=0.6$ and Current $=80$. - $4^{\text {th }}$ graph is between Feed and Flushing Pressure. The minimum value of $\mathrm{SR}$ is at Feed $=10$ and Flushing Pressure $=3$

- $5^{\text {th }}$ graph is between Feed and Current. The minimum value of $\mathrm{SR}$ is at Feed $=10$ and Current $=80$.

- $6^{\text {th }}$ graph is between Flushing Pressure and Current. The minimum value of SR is at Flushing Pressure $=3$ and Current $=80$.

Table 8. Confirmation Experiment Result for SR

\begin{tabular}{|c|c|c|}
\hline $\begin{array}{c}\text { Performance } \\
\text { Measures/ } \\
\text { Response }\end{array}$ & $\begin{array}{c}\text { Optimal Set of } \\
\text { Parameter }\end{array}$ & $\begin{array}{c}\text { Experimental } \\
\text { Value }\end{array}$ \\
\hline SR & $\begin{array}{c}\text { Tension- } 0.6 \mathrm{~N} \\
\text { Feed- } 10 \mathrm{~m} / \mathrm{min}\end{array}$ & 2.214 \\
& $\begin{array}{c}\text { Flushing Pressure- } \\
3 \mathrm{~kg} / \mathrm{cm}^{2}\end{array}$ & \\
& Current- $80 \mathrm{~A}$ & \\
\hline
\end{tabular}

From confirmation test we can concluded that our experimental value of surface roughness is less than the predicted value which means surface roughness achieved Tension- 0.6 N, Feed- 10m/min, Flushing Pressure$3 \mathrm{~kg} / \mathrm{cm}^{2}$, Current- $80 \mathrm{~A}$ is optimum.

\section{Conclusions of Surface Roughness for EDM wire cut}

1. It is noted that the minimum mean of surface roughness is 2.214 achieved at Tension- $0.6 \mathrm{~N}$, Feed$10 \mathrm{~m} / \mathrm{min}$, Flushing Pressure- $3 \mathrm{~kg} / \mathrm{cm}^{2}$, Current- $80 \mathrm{~A}$.
2. SR is increase by increasing the peak current. Because Increase the peak current increase the discharge energy.

\section{Scope of Future}

In this present work MRR and SR of machined product was studied during the machining of Tungsten carbide using EDM can futher be carried out to study the machining characterstic known as Hardness of machined surface, Properties of HAF etc.

\section{References}

1. S. H. lee, X. P. Li: [2001], "Study of the effect of machining parameters on the machining characteristics in electrical discharge machining of tungsten carbide"; Journal of material Processing Technology115, pp 344-358.

2. C. COGUN, S. Akaslan [2002], "The effect of machining parameters on Tool edge wear \& machining performance in EDM" KSME International Journal, vol, 16, No.1,pp 46-59

3. S.H. Lee*, X. Li, [2003] "Study of the surface integrity of the machined workpiece in the EDM of tungsten carbide"; Journal of Materials Processing Technology 139, pp 315-321

4. P.M. George, B.K. Raghunath, L.M. Manocha, A. M. Warrier [2003] "EDM machining of carboncarbon composite - a Taguchi approach", Journal of Materials Processing Technology, vol. 145, pp 66-71

5. N. Tosun, C. Cogun, A. Inan [2003] "The Effect of Cutting Parameters on Workpiece Surface Roughness in Wire EDM," Machining Science and Technology, vol. 7, pp. 209-219

6. I. Puertas, C.J. Luis [2003] "A study on the machining parameters optimisation of electrical discharge machining" Journal of Materials Processing Technology, Vol. 143 pp-521-526.

7. S.S Mahapatra, A. Patniak [2006] "Optimization of wire electrical discharge machining (WEDM) process parameters using Taguchi method" International Journal of Advance Manufacturing Technology

8. H.K. Kansal, S. Singh , P. Kumar [2007] "Technology and research developments in powder mixed electric discharge machining (PMEDM)" Journal of Materials Processing Technology, vol. 184 , pp 32-41

9. K. Furutani, H. Sato, M. Suzuki [2008] “Influence of electrical conditions on performance of electrical discharge machining with powder suspended in working oil for titanium carbide deposition process" Int J Adv Manuf Technol, vol. 40, pp 1093-1101 
10. J. Kapoor, S. Singh \& J.S. Khamba [2010] "Recent Developments in Wire Electrodes for High Performance WEDM' Proceedings of the World Congress on Engineering 2010 Vol II WCE 2010, June 30 - July 2, 2010, London, U.K.

11. M.P. Jahan, M.Rahman, Y.S.Wong [2011]: “ $A$ review on the conventional and microelectrodischarge machining of tungsten carbide"; International Journal of Machine Tools \& Manufacture 51 837-858

12. A. Klinka, Y.B. Guoa, F. Klockea [2011] "Surface integrity evolution of powder metallurgical tool steel by main cut and finishing trim cuts in wire-EDM", 1st CIRP Conference on Surface Integrity (CSI) Procedia Engineering 19, pp 178 - 183

13. H. Singh, D.K. Shukla [2012]: "Optimizing electric discharge machining parameters for tungstencarbide utilizing thermo-mathematical modelling"; International Journal of Thermal Sciences 59 (2012) $161-175$

14. E.Aliakbari, H. Baseri [2012]“Optimization of machining parameters in rotary EDM process by using the Taguchi method" Int J Adv Manuf Technol, Vol. 62, pp 1041-1053

15. D.Kanagarajan, K.Palanikumar, R.Karthikeyan [2012] "Effect of Electrical Discharge Machining on strength and reliability of WC-30\%Co composite" Materials and Design 39, pp 469-474

16. A.V. Shayan, R.A. Afza, R. Teimouri [2013]: "Parametric study along with selection of optimal solutions in dry wire cut machining of cemented tungsten carbide (WC-Co)"; Journal of Manufacturing Processes 15 644-658

17. K.P. Rajurkar, M.M. Sundaram, A.P. Malshe [2013] "Review of Electrochemical and Electrodischarge Machining", The Seventeenth CIRP Conference on Electro Physical and Chemical Machining (ISEM) Procedia CIRP 6 13-26

18. S. Assarzadeh*, M. Ghoreishi [2013] "Statistical modeling and optimization of process parameters in electro-discharge machining of cobalt-bonded tungsten carbide composite (WC/6\%Co)" The Seventeenth CIRP Conference on Electro Physical and Chemical Machining (ISEM) pp $463-468$

19. R. Demellayer*, J. Richard [2013] "High precision electro discharge machining of Molybdenum and Tungsten" The Seventeenth CIRP Conference on Electro Physical and Chemical Machining (ISEM), Procedia CIRP 6, pp 89 - 94

20. www.newagepublishers.com/.../001566.pdf 